\title{
Variants of $11 \beta$-hydroxysteroid dehydrogenase (HSD11B) gene type 1 and 2 in Chinese obese adolescents
}

\author{
Zou Chao Chun \\ From 7th APPES Biennial Scientific Meeting \\ Nusa Dua, Bali. 14-17 November 2012
}

\section{Objective}

To investigate the relationship between $11 \beta$-hydroxysteroid dehydrogenase $(H S D 11 B)$ gene type 1 and 2 and obesity in Chinese child.

\section{Methods}

A total of 400 obese and 200 healthy adolescents were enrolled as obese and control groups. Seven tagged SNPs in HSD11B1 (rs4393158, rs2235543, rs10082248, rs10863782, rs2236903, rs2298930, rs4545339) and 4 variants in HSD11B2 gene (rs28934592, rs28934591, rs28934594 and rs28934593) were measured by automated platform MassArray.

\section{Results}

The rs28934592 in HSD11B2 and rs10863782 in HSD11B1 were excluded as false positive or HWE $\mathrm{P}<0.05$. Moreover, one allele type was found in the other 3 locations of HSD11B2. The minor allele frequency of rs 2235543 and rs10082248 were higher in patients than these in controls $(\mathrm{P}=0.045, \mathrm{P}=0.041$, respectively). The $\mathrm{rs} 10082248$, rs2298930 and rs4545339 were associated with the risk of obesity in the recessive model $(\mathrm{P}<0.05$, respectively). Moreover, the total cholesterol in patients with GG or AG genotype was significantly higher than that in patients with AA genotype in rs10082248. The rs4393158 was associated with the hypertension inlog-additive model test $(\mathrm{P}=0.037)$, and glucose abnormal and hypercholesteremiaindominant model test $(\mathrm{P}<0.05$, respectively), while the rs2235543 was associated with hypercholesteremiainoverdominant model test $(\mathrm{P}=0.017)$.

The Children's Hospital Of Zhejiang University School Of Medicine, China

\section{Conclusion}

The polymorphism of HSD11B1 may be a cause of childhood obesity, or even associated with the complication of childhood obesity. However, variants of HSD11B2 may be not a cause of obesity.

Published: 3 October 2013

\section{doi:10.1186/1687-9856-2013-S1-P92}

Cite this article as: Chun: Variants of $11 \beta$-hydroxysteroid

dehydrogenase (HSD11B) gene type 1 and 2 in Chinese obese adolescents. International Journal of Pediatric Endocrinology 2013 2013(Suppl 1):P92.
Submit your next manuscript to BioMed Central and take full advantage of:

- Convenient online submission

- Thorough peer review

- No space constraints or color figure charges

- Immediate publication on acceptance

- Inclusion in PubMed, CAS, Scopus and Google Scholar

- Research which is freely available for redistribution

\section{( Biomed Central}

\section{Ciomed Central}

